\title{
RAB27A wt Allele
}

National Cancer Institute

\section{Source}

National Cancer Institute. RAB27A wt Allele. NCI Thesaurus. Code C119635.

Human RAB27A wild-type allele is located within 15q15-q21.1 and is approximately $116 \mathrm{~kb}$ in length. This allele, which encodes ras-related protein Rab-27A, is involved in the maturation and release of lymphocytic granules. Mutation of the gene is associated with Griscelli syndrome 2. 